\title{
Micro-Surgical Decompression for Greater Occipital Neuralgia
}

\author{
Büyük Oksipital Nervalji İcin Mikro Cerrahi Dekompresyonu
}

\author{
Fuyong LI, Yi MA, Jianjun ZOU, Yanfeng LI, Bin WANG, Haitao HUANG, Quancai WANG, Liang LI \\ The People's Hospital of Liaoning Province, the 2nd Department of Neurosurgery, Shenyang, China
}

Correspondence address: Jianjun ZOU / E-mail: 1fy986@sina.com

\begin{abstract}
AIM: To evaluate the clinical effect of micro-surgical decompression of greater occipital nerve for greater occipital neuralgia (GON).

MATERIAL and METHODS: 76 patients underwent surgical decompression of the great occipital nerve. A nerve block was tested before operation. The headache rapidly resolved after infiltration of $1 \%$ Lidocaine near the tender area of the nerve trunk.

RESULTS: 89 procedures were performed for 76 patients. The mean follow up duration was 20 months (range 7-52 months). The headache symptoms of $68(89.5 \%)$ patients were completely resolved, and another $5(6.6 \%)$ patients were significantly relieved without the need for any further medical treatment. Three (3.9\%) patients experienced recurrence of the disorder. All patients experienced hypoesthesia of the innervated area of the great occipital nerve. They recovered gradually within 1 to 6 months after surgery.

CONCLUSION: Micro-surgical decompression of the greater occipital nerve is a safe and effective method for greater occipital neuralgia. We believe our findings support the notion that the technique should also be considered as the first-line procedure for GON.
\end{abstract}

KEYWORDS: Headache, Greater occipital neuralgia, Surgical decompression

öz

AMAÇ: Büyük oksipital nevralji için büyük oksipital sinirin mikrocerrahi dekompresyonunun klinik etkisini değerlendirmek.

YÖNTEM ve GEREÇLER: Yetmiş altı hastada büyük oksipital sinirin cerrahi dekompresyonu yapılmıştır. Ameliyattan önce bir sinir bloğu test edilmiştir. Başağrısı sinir gövdesi yakınındaki hassas bölgeye \%1 Lidokain infiltrasyonuyla hızlı bir şekilde geçmiştir.

BULGULAR: Yetmiş altı hasta için 89 işlem yapıldı. Ortalama takip süresi 20 ay olmuştur (ortalama 7-52 ay). Altmış sekiz hastanın (\%89,5) başağrısı belirtileri tamamen geçerken ayrıca $5(\% 6,6)$ hastada daha ileri tıbbi tedavi gerektirmeyecek şekilde önemli ölçüde geçmiştir. Üç $(\% 3,9)$ hastada olay tekrarlamıştır. Tüm hastalar büyük oksipital sinirin enervasyon sağladığı bölgede hipoestezi yaşamıştır. Cerrahiden sonra 1-6 ay içinde zamanla iyileşme görülmüştür.

SONUÇ: Makör oksipital sinirin mikro cerrahi dekompresyonu majör oksipital nöralji için güvenli ve etkin bir yöntemdir. Bulgularımızın bu tekniğin büyük oksipital nevralji için birinci basamak tedavi olarak düşünülmesini desteklediğine inanıyoruz.

ANAHTAR SÖZCÜKLER: Başağrısı, Büyük oksipital nevralji, Cerrahi dekompresyon

\section{INTRODUCTION}

Greater occipital nerve neuralgia is a rare cause of severe cranial headache, and may be refractory to medical treatment $(1,7)$. Most patients present first at the neurological outpatient department, and are treated by medical methods, including analgesics and sedation. However, all the known methods have rarely produced ideal results so far. We performed surgical decompression as one of the promising functional methods for GON patients to resolve their symptoms.

\section{MATERIALS and METHODS}

\section{Patient population}

Eighty-nine micro-surgical decompressions were performed on 76 patients with classic symptoms of GON including 3 bilateral cases between Jan 2007 and Jan 2011. As shown in Table I, the average age was 58 years (range 47-78 years).
The mean follow-up duration was 20 months (range 7-52 months). All patients had preoperative MRI routinely to rule out secondary headache. Great occipital nerve block was performed as the patients underwent GON. Therefore, all diagnostic criteria for ICHD-II diagnosis 13.8 Occipital neuralgia [G52.80] were fulfilled.

\section{Inclusion and exclusion criteria}

Patients were included when the headache rapidly resolved after infiltration of $1 \%$ Lidocaine near the tender area of the nerve trunk. Patients were otherwise excluded.

\section{Surgical technique}

The surgical procedure was performed in the operating room. The patients were placed in the lateral position and ECG monitorization was performed for the elderly and patients who had previous cardiac problems. Once local anesthesia 
Table I: Characteristics of 76 Patients Who Underwent MicroSurgical Decompression for GON

$\begin{array}{ll}\text { Characteristic } & \text { Value } \\ \text { Sex (M/F) } & 46 / 30 \\ \text { Age (yrs) } & 58 \pm 9 \\ \text { Location } & \\ \quad \text { Left } & 33 \\ \quad \text { Right } & 40 \\ \text { Bilateral } & 3 \\ \text { Disorder duration (months) } & 26 \pm 12 \\ \text { Prior treatment } & \\ \quad \text { None } & 4 \\ \quad \text { Nerve block } & 16 \\ \quad \text { Drug therapy } & 73 \\ \quad \text { Acupuncture } & 42 \\ \text { Rate of recurrence (\%) } & 3.9 \\ \text { Time to recurrence (months) } & 8.7 \pm 3.2 \\ \text { Results are expressed as the mean } \pm \text { standard error of the mean. }\end{array}$

was successfully performed, a direct skin incision was made. The following procedures were then performed under microscopy (Zeiss S88, Germany). The subcutaneous tissue was dissected and the great occipital nerve was found. The GON emerged from the medial branch of the dorsal branch of the second cervical nerve. The nerve passed backwards between the inferior capitis oblique and the semispinal muscle and the aponeurosis of the trapezius muscle to emerge over the occiput. It traveled with the occipital artery from this point. This point was decompressed and relaxed thoroughly by dissecting part of the tendon. Swollen lymph nodes and the malformed vascular branches twining the great occipital nerve or its branches were dissected (Figure 1). Sometimes, parts of the muscles were dissected to decompress the nerve adequately. Careful homeostasis and suturing of subcutaneous tissue and skin were done routinely.

\section{Follow-up}

A questionnaire of a visual analogue scale (VAS) were used before and after surgery and at follow-up. There was no patient lost to follow up. Significant relief was defined as the patient having $75 \%$ less headaches.

\section{RESULTS}

Eighty-nine procedures were performed for 76 patients, including 13 bilateral GON cases (see Table II). Follow-up was conducted by telephone and letter. The mean follow up duration was 20 months (range 7-52 months). The headache symptoms of $68(76.4 \%)$ patients were completely resolved, another 5 (6.6\%) patients experienced significant relief without medical treatment. $3(3.9 \%)$ patients experienced recurrence, 1 (1.3\%) patient underwent repeat nerve decompression 6 months after the first decompression, and 2 (2.6\%) patients experienced recurrence 7 and 13 months after surgical decompression respectively. They refused repeat surgical
Table II: Results-Table

$\begin{array}{ll}\text { Characteristic } & \text { Value } \\ \text { Procedure } & 89(76+13) \\ \text { Bilateral } & 13 \\ \text { Mean follow-up } & 20 \text { months } \\ \text { Symptom } & \\ \text { Completely resolved } & 68(76.4 \%) \\ \text { Significantly relieved } & 5(6.6 \%) \\ \text { Recurrence } & 3(3.9 \%)^{*} \\ \text { Repeat operation } & 1(1.3 \%)\end{array}$

*including 1 patient that underwent repeat nerve decompression after first decompression 6 months ago.

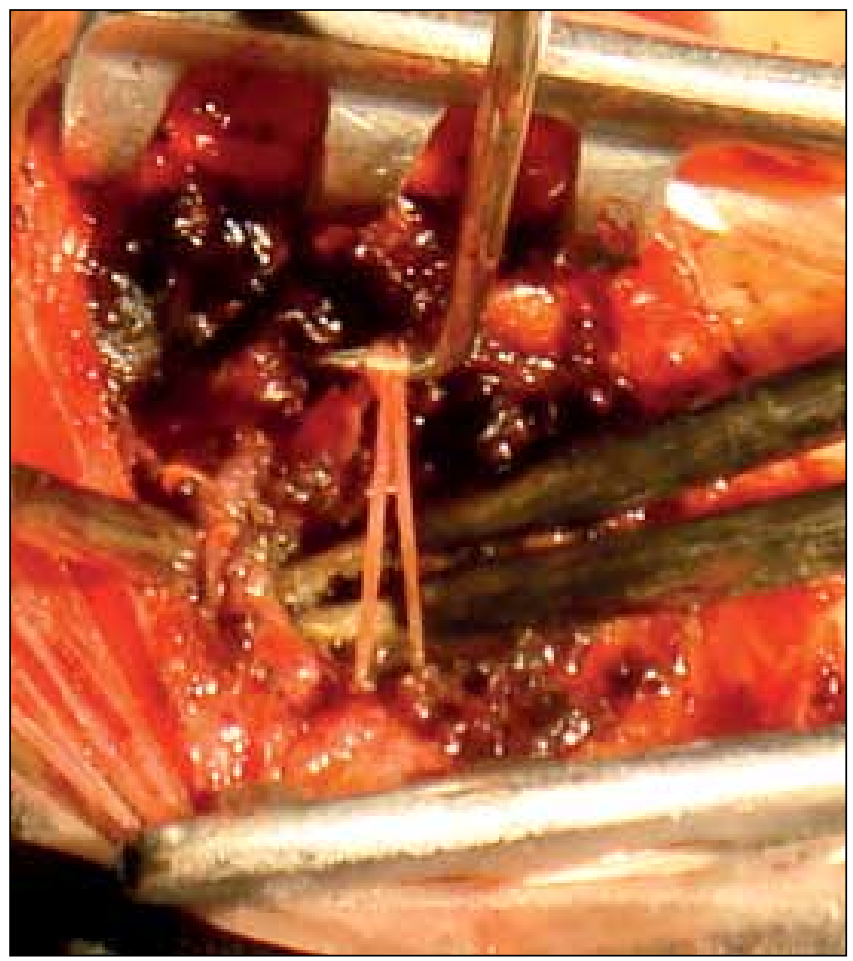

Figure 1: The GON was decompressed and relaxed thoroughly.

procedure as their symptoms were mild and they needed analgesics only occasionally. All the patients experienced hypoaesthesia of the innervated area of the great occipital nerve. They recovered to normal gradually within 1 to 6 months after surgery. There was no post-surgical complication besides hypoaesthesia.

\section{DISCUSSION}

Greater occipital nerve neuralgia is paroxysmal, lancinating pain located to the occipital skin region supplied by the greater occipital nerve, sometimes accompanied by dull, continuous pain $(1,4)$. It is a rare cause of severe cranial headache, and may be refractory to medical treatment. Most patients present first at the neurological outpatient department, and are treated by medical methods, including analgesics and 
sedation. However, all the methods usually produce non-ideal results. The cause is unknown. Many articles have noted an anatomical etiology in that the occipital nerve trunk and/or its branches were compressed $(2,5,8)$.

GON has traditionally been treated by drugs including analgesics and sedatives and local anesthesia (8) or acupuncture in China. All the methods only help to relieve the pain but do not provide cure.

Christiane Cornely (1) and his colleagues reported a 66-yearold woman who developed episodes of lancinating, severe pain in the right occipital region, correlating to the area of the nerve. Superficial vascular ultrasound showed a pathological nerve-vessel contact, with the occipital artery framing a vascular loop next to the structure of the nerve. The patient was treated by surgical decompression of the great occipital nerve. They found a close contact between the occipital artery and the nerve during surgery. Long distance decompression and neurolysis was performed. Neuralgic pain remained absent during a follow-up period of more than 1 year. Gille $\mathrm{O}$, et al. (3) treated greater occipital neuralgia by neurolysis of the greater occipital nerve and sectioning of the inferior oblique muscle and obtained an ideal outcome.

Based on the compression theory, we performed the surgical procedure under local anesthesia of the great occipital nerve area. During surgery, we found that the nerve was edematous due to compression by a swollen lymph node and malformed vascular branches twining with the great occipital nerve or its branches. This kind of compression does not usually cause headache. However, when the concentration of neural transmitters in the vessel changes, a nerve with pathological contact would be stimulated and the paroxysm of GON would develop.

The key point of the procedure is adequate decompression. The duration of surgery was very short, within 40 minutes in almost all patients, making us consider micro-surgical decompression to be a promising therapy for GON given its low risk and high effectiveness.

\section{CONCLUSION}

Compression of the great occipital nerve by close proximity of the muscle tendon membrane and/or the swelling lymph node and/or the occipital artery in the peripheral course of the nerve is a cause of occipital neuralgia, and surgical decompression represents a relatively easy treatment with longterm success. It could be considered a first-line treatment.

\section{ACKNOWLEDGEMENTS}

This study was supported by a grant from The People's hospital of Liaoning Province.

\section{CONFLICT OF INTEREST}

The authors report no conflicts of interest.

\section{REFERENCES}

1. Christiane Cornely, Marius Fischer, Giulio Ingianni, Isenmann S: Greater occipital nerve neuralgia caused by pathological arterial contact: Treatment by surgical decompression. Headache 4:609-612, 2011

2. Dhillon KS, Singh J, Lyall JS: A new horizon into the pathobiology, etiology and treatment of migraine. Med Hypotheses 77(1):147-151, 2011

3. Gille O, Lavignolle B, Vital JM: Surgical treatment of the greater occipital neuralgia by neurolysis of the greater occipital nerve and sectioning of the inferior oblique muscle. Spin 29 : 828-832, 2004

4. Kuhn WF, Kuhn SC, Gilberstadt H: Occipital neuralgias: Clinical recognition of a complicated headache: $A$ case series and literature review. J Orofac Pain 11:158-165,1997

5. Lin FY, Yang CY: Reversible splenial lesion of the corpus callosum in migraine with aura. Neurologist 17(3):157-159, 2011

6. Natsis K, Baraliakos X, Appell HJ, Tsikaras P, Gigis I, Koebke J: The course of the greater occipital nerve in the suboccipital region: A proposal for setting landmarks for local anesthesia in patients with occipital neuralgia. Clin Ana 19:332-336, 2006

7. Nikakis P, Koutsis G, Potagas C, Mandellos D, Sfagos C: Occipital neuralgia as an isolated symptom of C2 myelitis. Headache 46:1304-1306, 2006

8. Shimizu S, Oka H, Osawa S, Fukushima Y, Utsuki S, Tanaka R, Fujii K: Can proximity of the occipital artery to the greater occipital nerve act as a cause of idiopathic greater occipital neuralgia? An anatomical and histological evaluation of the artery-nerve relationship. Plast Reconstr Surg 119:2029-2034, 2007 